\title{
Exploring the Link between Operational Efficiency and Firms' Financial Performance: An Empirical Evidence from the Ghana Stock Exchange (GSE)
}

\author{
Mohammed Musah1, Yusheng Kong², Isaac Adjei Mensah ${ }^{3}$ \\ 1,3PhD Candidates, 2 Professor \\ 1,2,3jiangsu University, Zhenjiang, Jiangsu, P. R. China
}

\begin{abstract}
How to cite this paper: Mohammed Musah | Yusheng Kong | Isaac Adjei Mensah "Exploring the Link between Operational Efficiency and Firms' Financial Performance: An Empirical Evidence from the Ghana Stock Exchange (GSE)" Published in International Journal of Trend in Scientific Research and Development (ijtsrd), ISSN: 24566470, Volume-3 | Issue-4, June 2019, pp.842-848, URL: https://www.ijtsrd.c om/papers/ijtsrd23 954.pdf

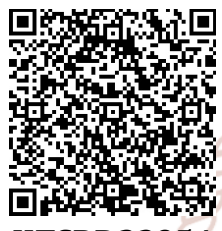
IITSRD23954
\end{abstract}

Copyright (C) 2019 by author(s) and International Journal of Trend in Scientific Research and Development Journal. This is an Open Access article distributed under the terms of the Creative Commons

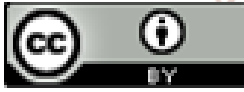
Attribution License (CC BY 4.0) (http://creativecommons.org/licenses/ by/4.0)

\section{ABSTRACT}

The purpose of this study was to explore the link between operational efficiency and the financial performance of non-financial firms listed on the Ghana Stock Exchange (GSE). Specifically, the study sought to determine the association between operational efficiency and the firms' financial performance as measured by ROA; examine the connection between operational efficiency and the firms' financial performance as measured by ROE; and to find out the affiliation between operational efficiency and the firms' financial performance as measured by ROCE. Panel data sourced from the audited and published annual reports of fifteen (15) listed non-financial firms for the period 2008 to 2017 was used for the study. From the study's Pearson Product-Moment Correlation Coefficient technique of data analysis, operational efficiency had a significantly negative association with the firms' financial performance as measured by ROA [ $\mathrm{r}=$ $0.2981,(p=0.0002)<0.05]$. Operational efficiency also had an insignificantly adverse relationship with the firms' financial performance as measured by ROE $[r=-0.0411,(p=0.6174)>0.05]$. Finally, operational efficiency had an insignificantly inverse affiliation with the firms' financial performance as measured by ROCE [ $r=-0.0055,(p=0.9471)>0.05]$. In order to have increased levels of financial performance, managers of non-financial firms listed on the Ghana Stock Exchange (GSE) should carefully plan and forecast their activities by taken into consideration, the fluctuations in their operational efficiency. This is because, operational efficiency have been widely proven to have a statistically significant relationship with firms' financial performance. The firms can also achieve viable operational efficiency by improving their capital base, reducing their operational costs, improving their asset quality, employing revenue diversification strategies as opposed to focused strategies, and by keeping the right amount of liquid assets.

Keywords: Operational Efficiency; Financial Performance; Ghana Stock Exchange (GSE)

\section{INTRODUCTION}

Neil (2019) viewed operational efficiency as the several techniques and strategies adopted to accomplish the basic goal of delivering quality goods and services to clients in the most cost-effective and timely manner. According to the author, resource utilization, production, distribution and inventory management are the most common aspects of operational efficiency. Kalluru and Bhat (2009) also explained operational efficiency as the proficiency of a corporation to curtail the unwelcomed and maximize resource capabilities so as to deliver quality products and services to customers.

As indicated by Ndolo (2015), operational efficiency is the key determinant of the long-term solvency of businesses. In fact, micro-economic or firm-specific predictors of corporates' financial health evolvesaround operational efficiency (Ndolo, 2015). Been in tandem with the view of Ndolo (2015), Sufian (2007) postulated that, improving operational efficiency has a direct impact on the profit margins of organisations. Operational efficiency is often achieved by streamlining firms' core processes in order to effectively respond to continually changing market forces in a more cost-effective manner (Vangie, 2019).

In other words, firms can attain operational efficiency by minimizing redundancy and waste while leveraging their resources that contribute mostly to their success; and also utilizing the best of their workforce, technology and business processes (Vangie, 2019). According to Vangie (2019), reduced internal costs that result from operational efficiency, help firms to be more successful in highly competitive markets, thereby achieving higher profit margins. The connection between operational efficiency and firms' financial performance has been widely studied. Inferences made drawn from these studies are however at variance. For instance, In India, Mistry (2012) conducted a 
study to examine the profitability determinants of the automobile industry. From the study's findings, operational efficiency proxied by the inventory turnover ratio, had a significantly positive association with the firms' profitability.

Santosuosso (2014) also analyzed the relationship between operational efficiency and the performance of 215 nonfinancial firms listed on the Italian Stock Exchange for the period 2004 to 2013. From the study's correlational results, operational efficiency had a weak association with the firms' profitability as measured by ROA and ROE.

Further, Navleen and Jasmindeep (2016) examined the profitability determinants of the Indian automobile industry for the period 2003-2004 to 2013-2014. Data from listed firms on the Bombay Stock Exchange (BSE) dealing in commercial vehicles, three wheelers, two wheelers and passenger vehicles were used for the study. From the study's correlational analysis, efficiency measured by the inventory turnover ratio and average payment period ratio had a significant affiliation with the firms' profitability. However, efficiency measured by the assets turnover ratio and the debtors turnover ratio had no significant relationship with the firms' profitability.

Gill, Singh, Mathur and Mand (2014) also examined the impact of operational efficiency on the future performance of firms listed on the Bombay Stock Exchange for the period 2008 to 2012. Adopting the weighted least squares method of data analysis, the study disclosed that operational efficiency surrogated by the assets turnover ratio had a positive link with the firms' future performance. Finally, Barus, Muturi and Kibati (2017) studied the influence of operational efficiency on the financial performance of Savings and Credit Cooperative Societies (SACCOS) in Kenya. Primary and secondary data from 83 SACCOS who were actively operating within the period 2011 to 2015 was employed for the study. From the study's findings, operational efficiency had an insignificantly adverse association with the SACCOS' financial performance.

All the aforementioned studies are flawed in scope in that, they failed to explore the strength and direction of the linear relationship that existed between operational efficiency and the financial performance of non-financial firms listed on the Ghana Stock Exchange (GSE). The studies are also flawed in scope because, they failed to use ROA, ROE and ROCE all together to examine the link between operational efficiency and firms' financial performance in one same study. This study was therefore viewed as timely and necessary to be undertaken to help fill those gaps. Specifically, the study sought to determine the association between operational efficiency and the firms' financial performance as measured by ROA; examine the connection between operational efficiency and the firms' financial performance as measured by ROE; and to find out the affiliation between operational efficiency and the firms' financial performance as measured by ROCE.

Findings of this study will add to the existing pool of literature on the connection between operational efficiency and firms' financial performance. This will serve as a reference material for students and researchers who may have the desire to conduct further studies on this current topic. The rest of the paper is arranged as follows; in part two of this study, reviews of relevant literature that supported the topic understudy are brought to light. The section also presents the study's formulated hypothesis. Section three of the study presents the research model and methodology; whilst the fourth section outlines the study's empirical results. In the fifth section, discussions and tests of the study's hypothesis are presented, whilst the conclusion and policy implications of the study form the last part of the report.

\section{LITERATURE REVIEW}

Meseret and Getahun (2017) examined the determinants of the financial performance of wheat flour producing firms in Hawassa City, South Ethiopia. Panel data from eight (8) flour manufacturing companies for the period 2008 to 2012 was used for the study. From the study's multiple regression output, assets utilization had a significantly adverse influence on the firms' financial performance as measured by ROA and ROE. InPakistan, Hongxing, Muhammad and Gulzara (2018) examined the profitability determinants of 28 banks for the period 2007 to 2016 . From the study's twostep Generalized Method of Momentum (GMM) system estimator, operational efficiency had a significantly inverse effect on the banks' profitability.

Ranjan and Bishnu (2017) delved into the determinants of the financial performance of textile sector firms listed on the Dhaka Stock Exchange. From the study's findings, operational efficiency represented by assets turnover had a significantly positive influence on the firms' financial performance as measured by ROA and EPS. Warrad and Rania (2015) examined the influence of turnover ratios on the Jordanian services sector. From the study's findings, efficiency measured by assets turnover, fixed assets turnover and working capital turnover had no significant impact on firms' profitability in the sector as measured by ROA and ROE. Innocent, Mary and Matthew (2013) conducted a study to examine the profitability determinants of the Nigerian pharmaceutical industry for the period 2001 to 2011. Findings of the study provided evidence of an insignificantly adverse connection between profitability and the firms' total assets turnover ratio, debt turnover ratio and creditor's velocity. However, a significantly converse relationship was found between inventory turnover ratio and the firms' profitability.

Gichuhi (2016) examined the influence of capital structure on the profitability of firms listed on the Nairobi Securities Exchange. Secondary data deduced from the annual reports of 36 listed firms for the period 2011 to 2015 was employed for the study. From the study's findings, operational efficiency had no significant association with the firms profitability. Memoona, Syed, Mobeen and Muhammad (2017) studied the effect of capital structure on the performance of non-financial firms in Pakistan. Data from 213 listed firms on the Karachi Stock Exchange for the period 1999 to 2015 was adopted for the study. From the study's full sample regression analysis, assets turnover being a control variable, had a significantly positive effect on the firms' financial performance as measured by ROA and ROE, but significantly negatively influenced the firms' financial performance through the PE ratio.

Mohd and Asif (2018) delved into the influence of liquidity, solvency and efficiency on the profitability of Steel Authority of India Limited (SAIL). Secondary data for the period 200506 to 2014-15 was employed for the study. From the study's 
multivariate regression analysis, efficiency as measured by the inventory turnover ratio had a significantly positive influence on the firm's financial performance as measured by ROA and ROCE. Mohammed, Ahmed and Mohammed (2016) investigated the influence of capital structure on the performance of consumer goods' companies listed on the Nigerian Stock Exchange. Secondary data sourced from the annual reports of seven (7) listed firms operating in consumer goods for the period 2008 to 2013 was employed for the study. From the study's findings, efficiency had an insignificant association with the firms' financial performance as measured by ROA.

Golchia (2014) examined factors that affected the profitability of firms in the Turkish tourism industry. Data for the period 1998 to 2011 was employed for the study. From the study's regression analysis, operational efficiency had an insignificant influence on the firms' profitability as measured by Return on Average Assets (ROAA) and Return on Average Equity (ROAE). Ashutosh and Gurpreet (2018) analyzed the financial performance of sugar mills in Punjab. Panel data from both co-operative and private sugar mills for the period 2003-04 to 2013-14 was adopted for the study. From the study's multivariate regression analysis, efficiency measured by the total assets turnover and the inventory turnover had a significant influence on the profitability of cooperative sugar mills in Punjab sugar industry.

Eniola and Memba (2016) studied the association between asset management and the financial performance of listed manufacturing firms in Nigeria. Data from 74 listed manufacturing firms for the period 2005 to 2014 was adopted for the study. Findings of the study established a significantly positive association between asset management and the firms' financial performance.

\subsection{Hypothesis Formulation}

Based on the review of relevant literature that supported the conduct of the study, the following hypothesis were developed for testing;

$\boldsymbol{H}_{0 \mathrm{~A}}: \quad$ Operational efficiency has no significant relationship with the firms' financial performance as measured by ROA.

$H_{O B}:$ Operational efficiency has no significant association with the firms' financial performance as measured by ROE.

$H_{\text {oc: }}$ Operational efficiency has no significant affiliation with the firms' financial performance as measured by ROCE.

\section{RESEARCH MODEL AND METHODOLOGY}

The quantitative research methodology was adopted for this study. The methodology was adopted because the study dealt with a numerical data. The quantitative research methodology was also adopted because the study aimed to establish facts and test formulated hypothesis. Thus, the study envisioned to find evidence that either supported or refuted some already established hypothesis. The study was specifically correlational in nature because its focus was to examine the strength and direction of the linear relationship between operational efficiency and the firms' financial performance. The study was finally panel because it involved the use and collection of data over a long period of time.

All non-financial firms that listed and traded their shares on the Ghana Stock Exchange (GSE) as of 31st December, 2017 formed the study's target population. Because the study wanted to deal with a balanced data, a sample was made out of the entire population. The number of years in existence, technical suspension due to one reason or the other, unaudited financial records, non-existence of trend records, incomplete financial statements and the presentation of annual reports in foreign currencies either than that of the Ghana currency (because of the non-stability of the Ghana Cedi to major foreign currencies) were the factors or filters that were considered during the sampling process.

Considering these factors or filters in making a choice out of the entire population implies, the study adopted the purposive or selective sampling technique in its sampling process. After critically considering the various factors or filters during the sampling process, fifteen (15) firms comprising of the Ghana Oil Company Ltd, Total Petroleum Ghana Ltd, Starwin Products Ltd, Camelot Ghana Ltd, Aluworks Ltd, Clydestone Ghana Ltd, African Champion Industries Ltd, Benson Oil Palm Plantation Ltd, Fan Milk Ltd, Guinness Ghana Breweries Ltd, Unilever Ghana Ltd, PZ Cussons Ghana Ltd, Produce Buying Company Ltd, Mechanical Lloyd Company Ltd and Sam Woode Ltd were selected for the study. This number represented $36.59 \%$ of the total number of listed firms or $53.57 \%$ of the total number of non-financial firms listed on the Ghana Stock Exchange (GSE).

A balanced secondary panel data extracted from the audited and published annual reports of the sampled firms for the period 2008 to 2017 was used for the study. The annual reports of the firms comprised of the comprehensive income statement, statement of financial position, statement of cash flows, statement of changes in equity and notes to the accounts. These annual reports were obtained from the official website of the Ghana Stock Exchange (GSE). Both the descriptive and inferential techniques of data analysis were employed for the study. In the descriptive technique of data analysis, the mean, standard deviation, variance, minimum and maximum values, range, skewness and kurtosis of the study's variables were analysed, whilst the Pearson ProductMoment Correlation Coefficient technique of data analysis was employed to establish the connection between operational efficiency and the firms' financial performance as measured by ROA, ROE and ROCE (inferential analysis). All the data analysis were conducted through the use of STATA version 15 statistical software package at an alpha $(\alpha)$ level of $5 \%(p \leq 0.05)$. Figure 1 shows the research model that guided the conduct of the study.

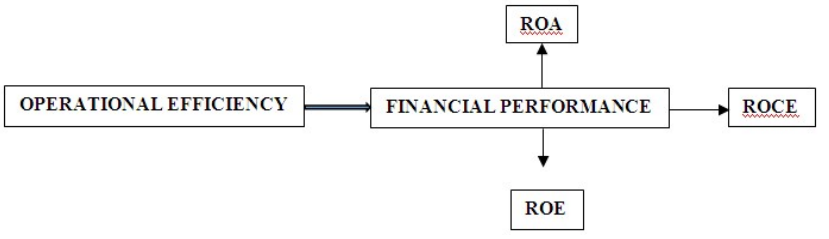

Fig.1. Research Model

Figure 1 shows that operational efficiency had an association with the firms' financial performance as measured by Return on Assets (ROA), Return on Equity (ROE) and Return on Capital Employed(ROCE). Return on assets was calculated as the ratio of net income to total assets of the firms. Return on equity was also calculated as the net income divided by the total equity of the firms, whilst the ratio of net income to capital employed was used to compute the firms' ROCE. On the other hand, operational efficiency was calculated as the ratio of gross revenue to total assets of the firms'. 


\section{EMPIRICAL RESULTS}

This section presents the empirical results of the study. First, results on the descriptive statistics of the study's variables are outlined; whilst the bivariate associations between operational efficiency and the firms' financial performance are finally brought to light.

\subsection{Descriptive Analysis of Study Variables}

The study's variables were first analyzed through the descriptive statistics of mean, standard deviation, variance, minimum and maximum values, range, skewness and kurtosis. As shown in Table 1, non-financial firms listed on the Ghana Stock Exchange (GSE), had a mean ROA of 0.0052693 , a standard deviation of 0.4849762 and a variance of 0.2352019 . This means, the ROA of the sampled firms deviated from both sides of the mean by0.4849762, implying, the ROA data values were not too widely dispersed from the mean. The maximum and minimum values of ROA were 0.7656 and -5.6487 respectively, leading to a range of 6.4143. The ROA distribution was negatively skewed with a coefficient of -10.64317. This shows that, the left tail of the ROA distribution was longer than that of the right tail. In other words, a large portion of the ROA distribution fell on the right side of the normal curve. The kurtosis coefficient of 124.8778 implies, the ROA distribution was not normally distributed. The sampled firms also had a mean ROE of 0.167214 , a standard deviation of 1.184918 and a variance of 1.404031. This is an indication that, the data values of ROE deviated from both sides of the mean by 1.184918, implying, the ROE data values were a bit widely dispersed from the mean. The maximum and minimum values of ROE were 12.8951 and -4.5277 respectively, leading to a range of 17.4228. The ROE distribution was positively skewed with a coefficient of 7.859589. This shows that, the right tail of the ROE distribution was longer than that of the left tail. In other words, a greater portion of the ROE distribution fell on the left side of the normal curve. The kurtosis coefficient of 91.75657 shows that, the ROE distribution was not of normal shape.

Table 1: Descriptive Statistics on Study Variables

\begin{tabular}{|c|c|c|c|c|c|c|c|c|c|}
\hline Variable & Obs & Mean & S.D & Variance & Min. & Max. & Range & Skewness & Kurtosis \\
\hline ROA & 150 & 0.0052693 & 0.4849762 & 0.2352019 & -5.6487 & 0.7656 & 6.4143 & -10.64317 & 124.8778 \\
\hline ROE & 150 & 0.167214 & 1.184918 & 1.404031 & -4.5277 & 12.8951 & 17.4228 & 7.859589 & 91.75657 \\
\hline ROCE & 150 & 0.1945633 & 1.09571 & 1.20058 & -1.5666 & 12.8951 & 14.4617 & 10.44939 & 122.057 \\
\hline EFFICIENCY & 150 & 1.647483 & 1.430299 & 2.045754 & 0.1908 & 7.9236 & 7.7328 & 1.616951 & 5.100983 \\
\hline
\end{tabular}

Further, the sampled firms had a mean ROCE of 0.1945633 , a standard deviation of 1.09571 and a variance of 1.20058 . This indicates that, the data values of ROCE deviated from both sides of the mean by 1.09571,implying, the ROCE data values were a bit widely dispersed from the mean. The maximum and minimum values of ROCE were 12.8951 and -1.5666 respectively, leading to a range of 14.4617. The ROCE distribution was positively skewed with a coefficient of 10.44939 . This shows that, the right tail of the ROCE distribution was longer than that of the left tail. Put simply, a large portion of the ROCE distribution fell on the left side of the normal curve. The kurtosis coefficient of 122.057 implies, the ROCE distribution was of abnormal shape. Finally, the sampled firms had a mean value of 1.647483 , a standard deviation of 1.430299 and a variance of 2.045754 for their operational efficiency. This is an indication that, the efficiency distribution was a bit widely departed

from the average. Operational efficiency also had a minimum value of 0.1908 and a maximum value of 7.9236 , leading to a range of 7.7328. The distribution for operational efficiency was positively skewed with a coefficient of 1.616951 . This is an indication that, a greater portion of the data values for operational efficiency fell on the left side of the normal curve. Operational efficiency had a kurtosis value of 5.100983 [excess $(K)=5.100983-3=2.100983]$. This implies, the distribution for operational efficiency was of higher and peakier shape.

\subsection{Bivariate Associations between Operational Efficiency and Firms' Financial Performance}

The Pearson Product-Moment Correlation Coefficient technique of data analysis was employed to assess the bivariate associations between operational efficiency and the firms' financial performance, and from Table 2, operational efficiency had a significantly negative affiliation with the firms' financial performance as measured by ROA $[\mathrm{r}=-0.2981,(\mathrm{p}=0.0002)<0.05]$. The adverse correlation between operational efficiency and ROA is an indication that, an increase in operational efficiency led to a decrease in ROA and vice-versa. The degree of association between operational efficiency and ROA can be substantiated by the coefficient of determination $\left(\mathrm{r}^{2}=0.0889\right)$ which shows that $8.89 \%$ of the variations in ROA was accounted for by operational efficiency and $8.89 \%$ of the variations in operational efficiency was explained by ROA. The unexplained variances [91.111\% or $\left.\left(1-\mathrm{r}^{2}=0.9111\right)\right]$ may be accounted for by other variables that did not form part of the study.

Table 2: Correlational Matrix of Study Variables

\begin{tabular}{|c|c|c|c|c|}
\hline Variable & ROA & ROE & ROCE & EFFICIENCY \\
\hline ROA & 1.0000 & & & \\
\hline ROE & $\begin{array}{c}0.0037 \\
(0.9642)\end{array}$ & 1.0000 & & \\
\hline ROCE & $\begin{array}{c}-0.0156 \\
(0.8498)\end{array}$ & $\begin{array}{c}0.9516^{*} \\
(0.0000)\end{array}$ & 1.0000 & \\
\hline EFFICIENCY & $\begin{array}{c}-0.2981^{*} \\
(0.0002)\end{array}$ & $\begin{array}{c}-0.0411 \\
(0.6174)\end{array}$ & $\begin{array}{c}-0.0055 \\
(0.9471)\end{array}$ & 1.000 \\
\hline
\end{tabular}

Note: ${ }^{*}$ implies significance at $5 \%$ and values in parenthesis () represent probabilities. 
The study also discovered an insignificantly adverse relationship between operational efficiency and the firms' ROE at the 95\% confidence interval [r= -0.0411, $(p=0.6174)>0.05]$. Even though the link between operational efficiency and the firms' ROE was trivial, the negative connection between them is still an indication that, an increase in operational efficiency led to a decrease in ROE and vice-versa. The strength of association between operational efficiency and the firms' ROE can be proven by the coefficient of determination $\left(r^{2}=0.002\right)$ which shows that $0.2 \%$ of the variations in ROE was explained by operational efficiency and $0.2 \%$ of the variations in operational efficiency was accounted for by ROE. The remaining $99.80 \%$ or $\left(1-\mathrm{r}^{2}\right.$ $=0.9980$ ) being the unexplained variances, may be attributed to other inherent variabilities.

Finally, operational efficiency was insignificantly negatively related to the firms' ROCE at $\alpha=5 \% \quad[\mathrm{r}=-0.0055$, $(p=0.9471)>0.05]$. Though, the affiliation between operational efficiency and the firms' ROCE was not significant, the adverse association between the two variables still depicts that, an increase in operational efficiency led to a decrease in ROCE and vice-versa. The weight of association between operational efficiency and the firms' ROCE can be justified by the coefficient of determination $\left(r^{2}=0.00003\right)$ which shows that $0.003 \%$ of the variations in ROCE was accounted for by operational efficiency and $0.003 \%$ of the variations inoperational efficiency was explained by ROCE. The unexplained variances [99.997\% or $\left.\left(1-r^{2}=0.99997\right)\right]$ may be related to other factors that did not form part of the study.

\section{DISCUSSIONS AND TESTS OF HYPOTHESIS}

In this part of the paper, discussions on the major findings of the study are outlined. The discussions are conducted in relation to the review of relevant literature that supported the topic understudy and are presented in the order of; the relationship between operational efficiency and the firms financial performance as measured by ROA; the association between operational efficiency and the firms' financial performance as measured by ROE; and the link between operational efficiency and the firms' financial performance as measured by ROCE. Each sub-section concludes with the test of a hypothesis that was formulated for the study.

\subsection{Relationship between Operational Efficiency and the Firms' Financial Performance (ROA)}

From the study's findings, operational efficiency had a significantly negative affiliation with the firms' financial performance as measured by ROA [r= -0.2981, $(p=0.0002)<0.05]$. This finding supported that of Meseret and Getahun (2017) whose research on eight (8) wheat flour manufacturing companies in Hawassa City, South Ethiopia, established asignificantly negative association between assets' utilization and the firms' financial performance as measured by ROA and ROE. The finding also supported that of Hongxing, Muhammad and Gulzara (2018) whose GMM study on 28 banks in the Islamic Republic of Pakistan, discovered a significantly inverse connection between operational efficiency and the banks' profitability. The finding was however inconsistent with that of Ranjan and Bishnu (2017) whose research on textile sector firms listed on the Dhaka Stock Exchange, uncovered a significantly positive affiliation between operational efficiency and the firms' financial performance as measured by ROA and EPS. The finding was also inconsistent with that of Warrad and
Rania (2015) whose study on the Jordanian services sector, found no significant link between operational efficiency and the firms' profitability as measured by ROA and ROE.

\subsubsection{Test of Hypothesis}

A significantly inverse association between operational efficiency and the firms' ROA was discovered at the 95\% confidence interval $\quad[r=-0.2981,(p=0.0002)<0.05]$. The study therefore failed to accept the null hypothesis $\left(H_{O A}\right)$ that, operational efficiency had no significant relationship with the firms' financial performance as measured by ROA, and concluded that, operational efficiency had a significantly negative connection with the firms' financial performance as measured by ROA.

\subsection{Association between Operational Efficiency and the Firms' Financial Performance (ROE)}

The study also discovered an insignificantly adverse relationship between operational efficiency and the firms' ROE at the 5\% significance level $[\mathrm{r}=-0.0411$, $(p=0.6174)>0.05]$. This finding was in line with that of Innocent, Mary and Matthew (2013) whose study on the pharmaceutical industry in Nigeria, found an insignificantly negative association between profitability and the firms' total assets turnover ratio, debt turnover ratio and creditor's velocity. The finding was also in agreement with that of Gichuhi (2016) whose research on 36 listed firms on the Nairobi Securities Exchange, discovered no significant association between operational efficiency and the firms' profitability. The finding was however inconsistent with that of Memoona, Syed, Mobeen and Muhammad (2017) whose study on 213 non-financial firms listed on the Karachi Stock Exchange, disclosed a significantly positive relationship between operational efficiency and the firms' financial performance as measured by ROA and ROE. The finding was also inconsistent with that of Mohd and Asif (2018) whose research on the Steel Authority of India Limited (SAIL), found a significantly positive link between operational efficiency and the firms' financial performance.

\subsubsection{Test of Hypothesis}

An insignificantly adverse affiliation between operational efficiency and the firms' ROE was discovered at the 5\% significance level $[r=-0.0411,(p=0.6174)>0.05]$. The study therefore failed to reject the null hypothesis $\left(H_{0 B}\right)$ that, operational efficiency had no significant affiliation with the firms' financial performance as measured by ROE, and concluded that, operational efficiency had an insignificantly inverse relationship with the firms' financial performance as measured by ROE.

\subsection{The Link between Operational Efficiency and the Firms' Financial Performance (ROCE)}

Finally, operational efficiency was insignificantly negatively related to the firms' ROCE at $\alpha=5 \% \quad[r=-0.0055$, $(\mathrm{p}=0.9471)>0.05]$. This finding was in tandem with that of Mohammed, Ahmed and Mohammed (2016) whose research on seven (7) consumer goods' companies listed on the Nigerian Stock Exchange, uncovered an insignificant association between operational efficiency and the firms' financial performance. The finding was also consistent with that of Golchia (2014) whose study on the Turkish tourism industry, found an insignificant link between operational efficiency and the firms' profitability. The finding was however inconsistent with that of Ashutosh and Gurpreet (2018) whose research on sugar mills in Punjab, India, found 
a significant bond between profitability and the firms' total assets turnover and inventory turnover ratios. The finding was also not consistent with that of Eniola and Memba (2016) whose research on 74 listed manufacturing firms in Nigeria, established a significantly positive association between asset management and the firms' financial performance.

\subsubsection{Test of Hypothesis}

An insignificantly negative relationship was found between operational efficiency and the firms' ROCE at the $95 \%$ confidence interval $[\mathrm{r}=-0.0055,(\mathrm{p}=0.9471)>0.05]$. The study therefore failed to reject the null hypothesis $\left(H_{0 C}\right)$ that, operational efficiency had no significant connection with the firms' financial performance as measured by ROCE, and concluded that, operational efficiency had an insignificantly adverse association with the firms' financial performance as measured by ROCE.

Table 3: Summary of the Test of Hypothesis

\begin{tabular}{|c|c|c|}
\hline \multicolumn{1}{|c|}{ Hypothesis } & $\begin{array}{c}\text { Analytical } \\
\text { Tool }\end{array}$ & Result \\
\hline $\begin{array}{l}H_{O A}: \text { Operational efficiency has } \\
\text { no significant relationship } \\
\text { with the firms' financial } \\
\text { performance as measured } \\
\text { by ROA. }\end{array}$ & Correlation & Rejected \\
\hline $\begin{array}{l}H_{O B}: \text { Operational efficiency has } \\
\text { no significant association } \\
\text { with the firms' financial } \\
\text { performance as measured } \\
\text { by ROE. }\end{array}$ & Correlation & Accepted \\
\hline $\begin{array}{l}H_{O C}: \text { Operational efficiency has } \\
\text { no significant affiliation } \\
\text { with the firms' financial } \\
\text { performance as measured } \\
\text { by ROCE. }\end{array}$ & Correlation & Accepted \\
\hline \multicolumn{2}{|l}{} & Internat \\
\hline
\end{tabular}

\section{CONCLUSION AND POLICY IMPLICATIONS}

This study sought to explore the link between operational efficiency and the financial performance of non-financial firms listed on the Ghana Stock Exchange (GSE). Specifically, the study sought to determine the association between operational efficiency and the firms' financial performance as measured by ROA; examine the connection between operational efficiency and the firms' financial performance as measured by ROE; and to find out the affiliation between operational efficiency and the firms' financial performance as measured by ROCE. Panel data sourced from the audited and published annual reports of fifteen (15) listed nonfinancial firms for the period 2008 to 2017 was used for the study. From the study's Pearson Product-Moment Correlation Coefficient technique of data analysis, operational efficiency had a significantly negative association with the firms' financial performance as measured by ROA [r= -0.2981, $(p=0.0002)<0.05]$. Operational efficiency also had an insignificantly adverse relationship with the firms' financial performance as measured by ROE [ $r=-0.0411,(p=0.6174)>0.05]$. Finally, operational efficiency had an insignificantly inverse affiliation with the firms' financial performance as measured by ROCE $\quad[r=-0.0055,(p=0.9471)>0.05]$. In order to have increased levels of financial performance, managers of nonfinancial firms listed on the Ghana Stock Exchange (GSE) should carefully plan and forecast their activities by taken into consideration, the fluctuations in their operational efficiency. This is because, operational efficiency have been widely proven to have a statistically significant relationship with firms' financial performance. The firms can also achieve viable operational efficiency by improving their capital base, reducing their operational costs, improving their asset quality, employing revenue diversification strategies as opposed to focused strategies, and by keeping the right amount of liquid assets.

\section{REFERENCES}

[1] Ashutosh, G., \& Gurpreet, R. (2018). Financial performance of sugar mills in Punjab: A comparative study. Indian Journal of Accounting (IJA), 50 (1), 87-96.

[2] Barus, J. J., Muturi, W., \& Kibati, P., (2017). Effect of capital adequacy on the financial performance of savings and credit societies in Kenya. American Journal of Finance, 1(4), 1-12.

[3] Eniola, V. O., \& Memba, F. (2016). Relationship between asset management and financial performance of listed manufacturing firms in Nigeria. International Journal of Social Sciences and Information Technology, II(IX), 1258-1277.

[4] Gichuhi, N. L. (2016). The effect of capital structure on profitability of firms listed at the Nairobi Securities Exchange. An Unpublished Research Project Submitted for the Award of the Degree of Master of Business Administration (MBA), School of Business, University of Nairobi.

[5] Gill, A., Singh, M., Mathur, N., \& Mand, H. S. (2014). The impact of operational efficiency on the future performance of Indian manufacturing firms. International Journal of Economics and Finance, 6(10), 259-269.

[6] 70 Golchia, M. (2014). Determinants of profitability in tourism industry: Evidence from Turkey. Thesis Submitted to the Institute of Graduate Studies and Research in Partial Fulfillment of the Requirements for the Degree of Master of Science in Banking and Finance, Eastern Mediterranean UniversityGazimağusa, North Cyprus.

[7] Hongxing, Y., Muhammad, H., \& Gulzara, T. (2018). Profitability determinants of financial institutions: Evidence from banks in Pakistan. International Journal of Financial Studies, 6(53), 1-28, DOI: $10.3390 /$ ijfs 6020053

[8] Innocent, E. C., Mary, O. I., \& Matthew, O. M. (2013). Financial ratio analysis as a determinant of profitability in Nigerian pharmaceutical industry. International Journal of Business and Management, 8(8), 107-117.

[9] Kalluru, S., \& Bhat, K. (2009). Determinants of cost efficiency of commercial banks in India. ICFA Journal of Bank Management, 8(2), 32-50.

[10] Memoona, K., Syed, J. H. S., Mobeen, R., \& Muhammad, Z. (2017). Impact of capital structure on performance of non-financial listed companies in Pakistan. Pakistan Business Review July 2017, 339-353.

[11] Meseret, T., \& Getahun, K. (2017). Determinants of financial performance of wheat flour producing companies in Hawassa City, South Ethiopia. Journal of 
Poverty, Investment and Development, Vol. 31, 2017, pp. 7-12, ISSN: 2422-846X

[12] Mistry, D. S. (2012). Determinants of profitability in Indian automotive industry. Tecnia Journal of Management Studies, $\quad$ 7(1), 20-23.

[13] Mohammed, M. K., Ahmed, B. B., \& Mohammed, A. (2016). Effect of capital structure on performance of listed consumer goods companies in Nigeria. Research Journal of Accounting and Finance, 7(8), 211-219.

[14] Mohd, Y., \& Asif, P. (2018). Impact of liquidity, solvency and efficiency on profitability of steel authority of India limited. International Journal of Research in Management, Economics and Commerce, 06(09), 25-31.

[15] Navleen, K., \& Jasmindeep, K. (2016). Determinants of profitability of automobile industry in India. Journal of Commerce and Accounting Research, Vol. 5, Issue 3. DOI: $10.21863 /$ jcar/2016.5.3.034

[16] Ndolo, P. S. (2015). The relationship between operational efficiency and financial performance of firms listed at the Nairobi Securities Exchange. A Research Project Presented in Partial Fulfillment of The Requirements for the Award of the Degree of Master of Science Finance, School of Business, University of Nairobi.
[17] Neil, K. (2019). What is the meaning of operational efficiency? Retrieved from https://smallbusiness.chron.com/meaningoperational-efficiency-67982.html

[18] Ranjan, K. M., \& Bishnu, K. A. (2017). Determinants of financial performance: Empirical evidence from the textile sector in Bangladesh. Journal of Accounting and Finance, 17(8), 110-120.

[19] Santosuosso, P. (2014). Do efficiency ratios help investors to explore firm performances? Evidence from Italian listed firms. International Business Research, 7(12), 111-119.

[20] Sufian, F. (2007). The efficiency of Islamic banking industry: A non-parametric analysis with nondiscretionary input variable. Islamic economic studies, 14 (1\&2).

[21] Vangie, B. (2019). Operational efficiency. Retrieved from

https://www.webopedia.com/TERM/O/operational_ efficiency.html

[22] Warrad, L., \& Rania, A. O. (2015). The impact of turnover ratios on Jordanian services sectors' performance. Journal of Modern Accounting and Auditing, 11(2), 77-85.

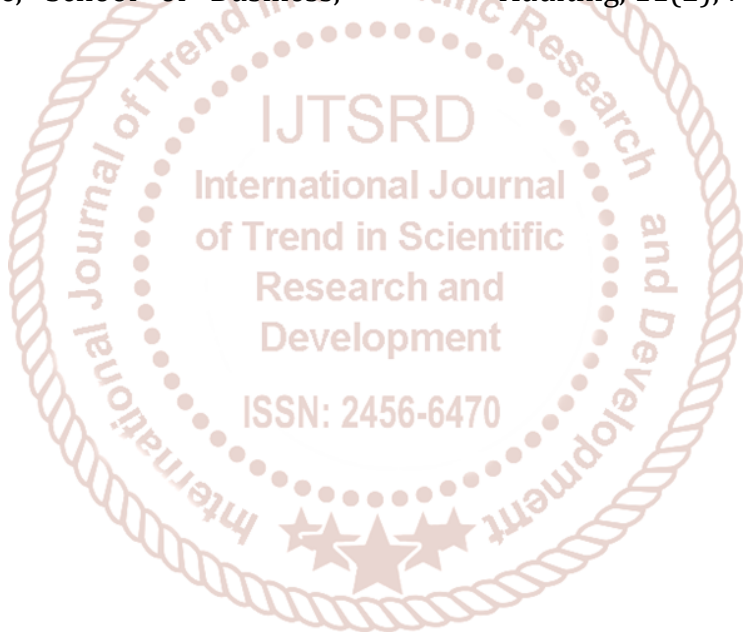

